\title{
الأحاديث الواردة \\ في فضائل الصتلاة على النبي صلى الله عليه وسلم في يوم الجمعة \\ جمع ودراسة
}

مكتوب/ أحمس أشُرفس عمر لبهيا

الأستاذ المشارك في الحديث وعلومه

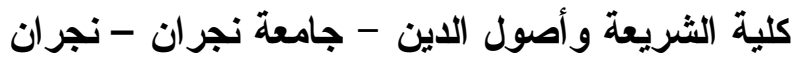

المملكة العربية السعودية المبية

الحمد لله رب العالمين، و الصلاة والسلام على نبينا محمد و على آله وصحبه أجمعين،

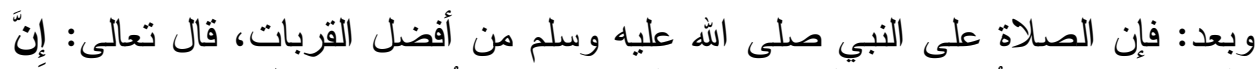

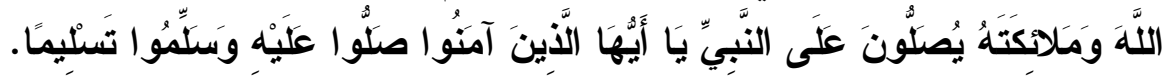
وقد ألف الأئمة كتبا في فضل الصلاة على النبي صلى اله عليه وسلم منها: (1)فضل الصلاة على النبي صلى الله عليه وسلم لإسماعيل بن إسحاق القاضي

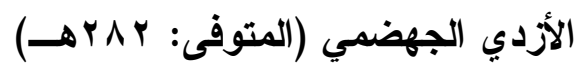

(Y)كتاب الصلاة على النبي صلى الله عليه وسلم لأبي بكر بن أبي عاصم

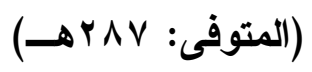

(r) جزء فيه طرق حديث عبد الرحمن بن أبي ليلى عن كعب بن عجرة في

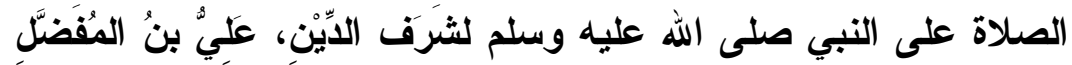

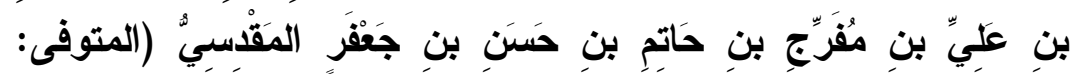

$$
\text { ( } 1711
$$

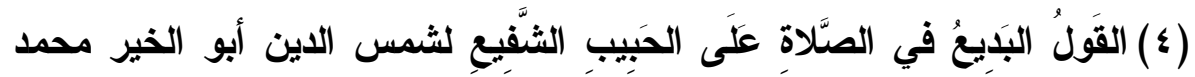

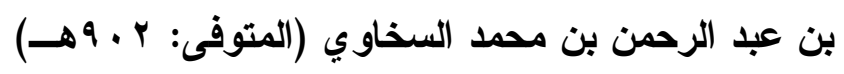

(•)جلاء الأفهام في فضل الصلاة والسلام على محمد خير الأنام لمحمد بن أبي

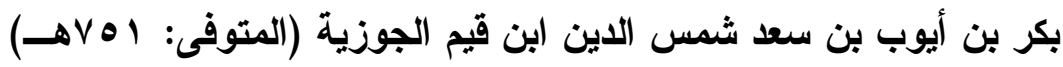


ثم رويت في الأحاديث تقييدات زمنية ومكانية للصلاة على النبي صلى الله عليه وسلم، واخترت منها ما ورد في فضل تقيبدها بيوم الجمعة لما اشتهر بين الناس، ولم أجد أحدا عُني بجمعه ودر استه ونقده على منهج أئمة الحديث المحققين.

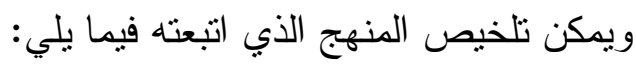
- جمعت من كتب الحديث الأحاديث في فضل الصلاة على النبي صلى الله عليه وسلم يلمي

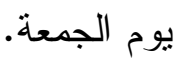
- خرجت تلك الأحاديث تخريجا علميا.

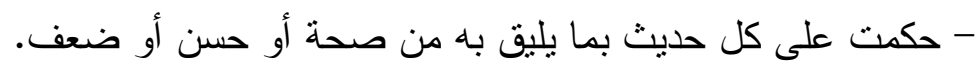
وقد جعلت البحث بعد المقدمة في ثمانية مباحث:

المبحث الأول: أصح ما ورد في فضل الصلاة على النبي صلة اله عليه وسلم إجمالا المبحث الثاني: فضيلة عرض الأعمال على النبي صلى الله عليه وسلم يوم الجمعة

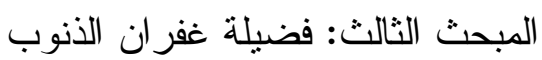
المبحث الر ابع : فضيلة قضاء الحوائج المبحث الخامس : فضيلة شهود الملائكة. المبحث السادس: فضيلة صلاة الله وملائكته على من صلى على على النبي

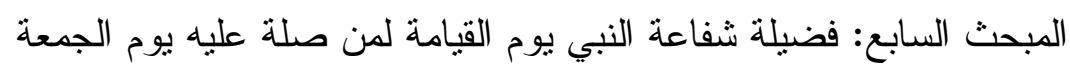
المبحث الثامن: فضيلة رؤية المقعد في الجنة فيلة فئة فئة

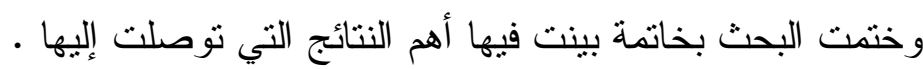

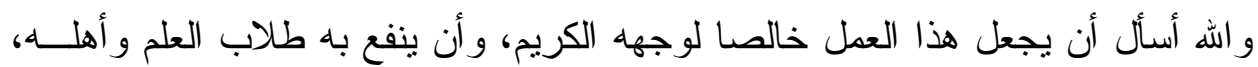

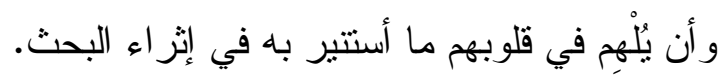

وكتبه: د. أحمد أثرف عمر لبي

نجران - المملكة العربية السعودية لفية 
الحديث الأول:

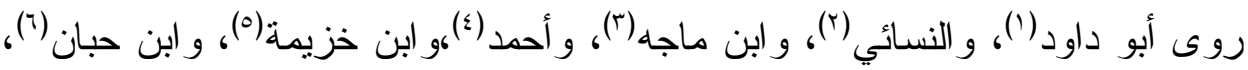

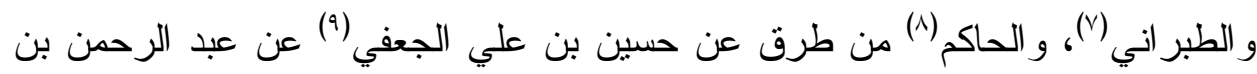

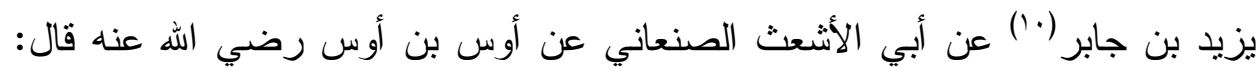

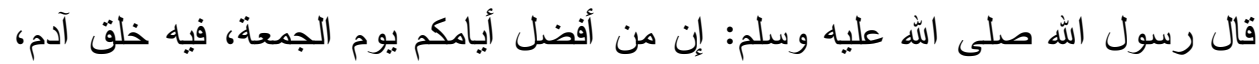
وفيه قبض، وفيه النفخة، وفيه الصعقة، فأكثروا عليَّ من الصلاة فيه، فإن صلاتكم

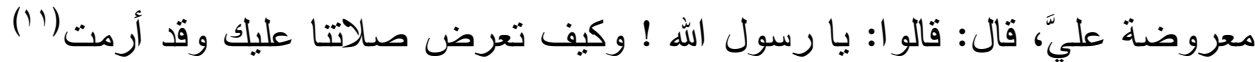
؟! فقال: إن اله عز وجل حرم على الأرض أجساد الأنبياء.

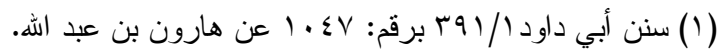

$$
\text { (Y) }
$$

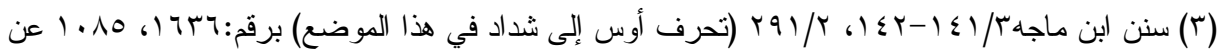

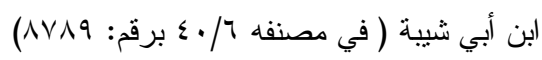

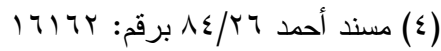

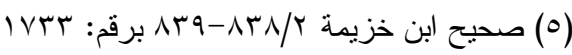

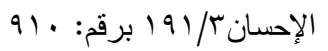

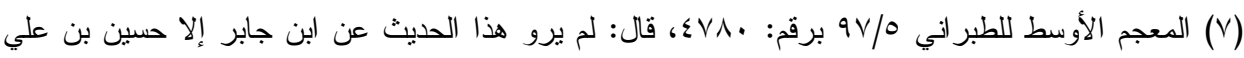

(9) هو الحسين بن علي بن الوليد الجعفي مو لاهم أبو عبد الله الكوفي المقرئ، ثقة عابد، روى له الستة ( تهذيب الهيب

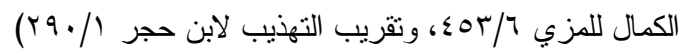

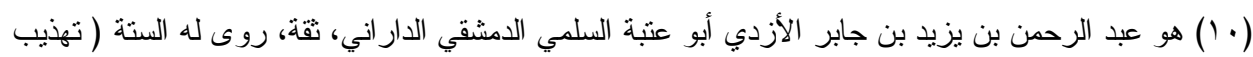

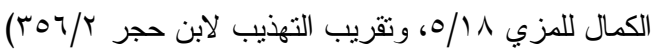

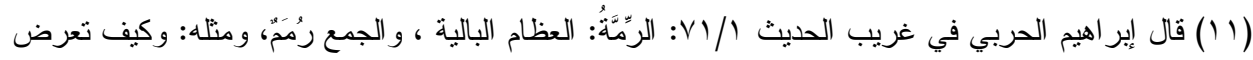

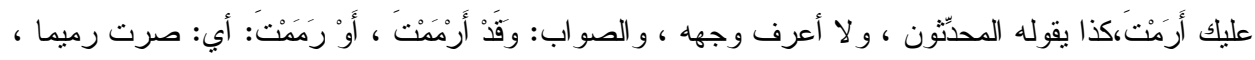

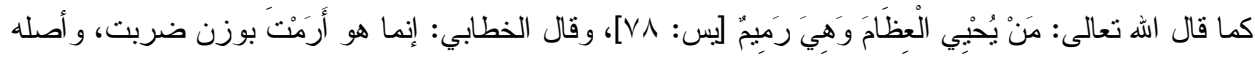

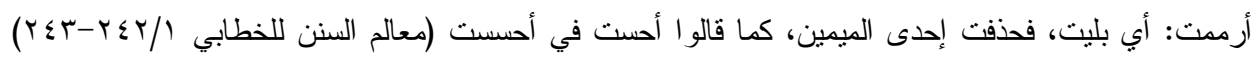

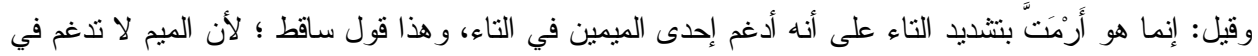

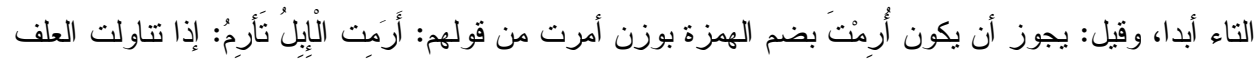

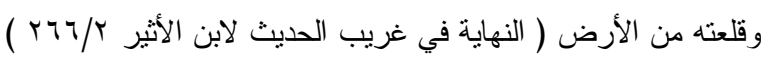


صححه ابن خزيمة وابن حبان، و الحاكم، و النووي(')

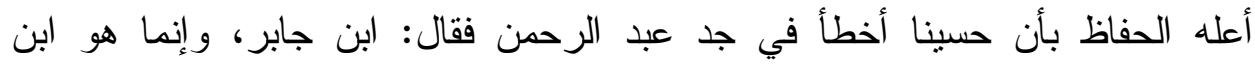

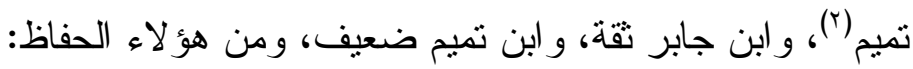

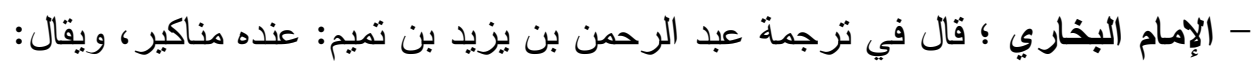

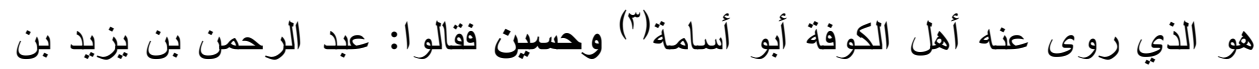

جابر (๕)

وقال الترمذي: قال محمد (البخاري): أهل الكوفة يروون عن عبد الرحمن بن يزيد بن

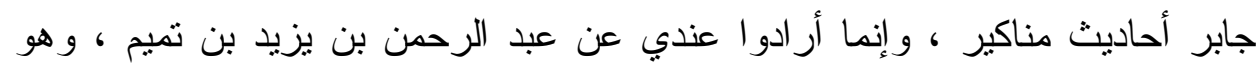

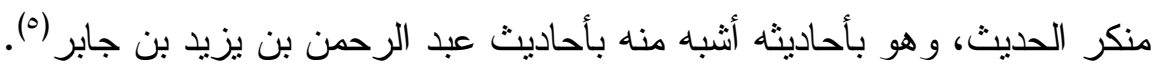

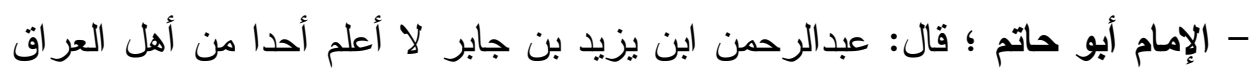

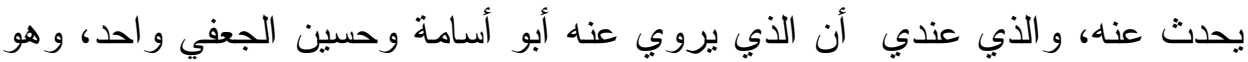

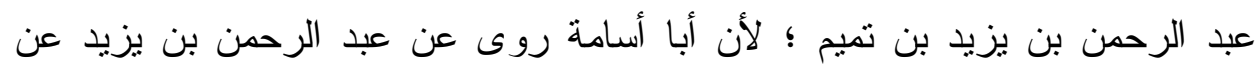

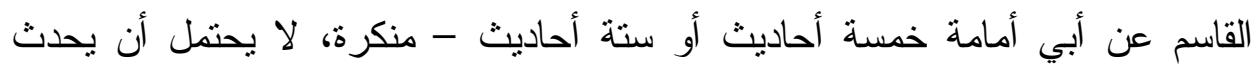

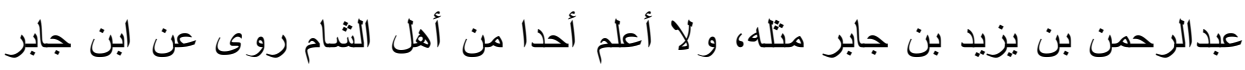

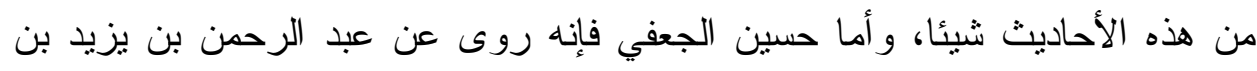
جابر عن أبي الأشعث عن أوس بن أوس عن النبي صلى الله عليه وسلم في يوم

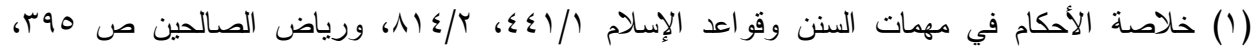

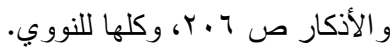

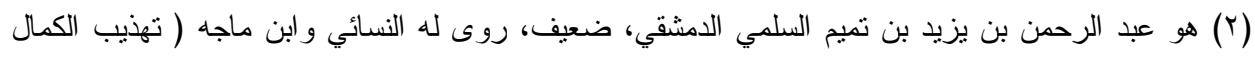

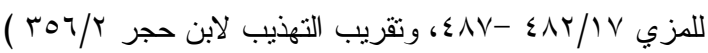

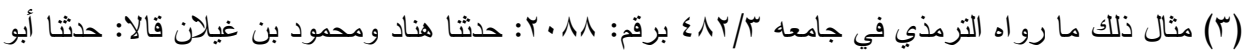

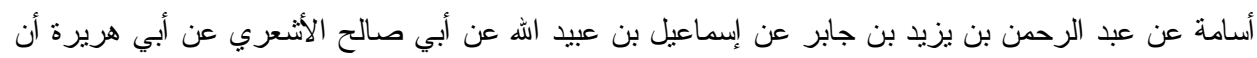

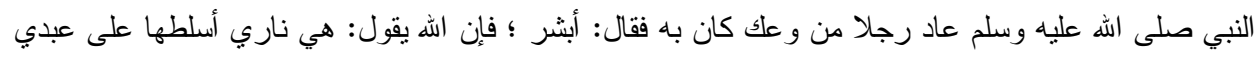

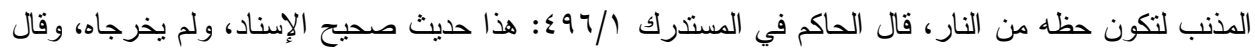

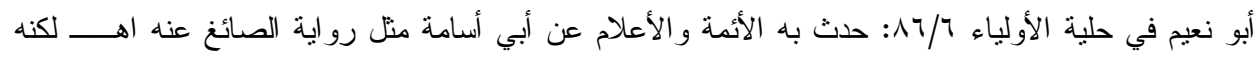


الجمعة أنه قال: أفضل الأيام يوم الجمعة ؛ فيه الصعقة، وفيه النفخة، وفيه كذا، وهو حديث منكر، لا أعلم أحدا رو اه غير حسين الجعفي، و أما عبدالرحمن بن بزيد بن تميم

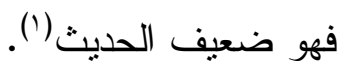
وقال أبو حانم أيضا: سألت محمد بن عبد الرحمن ابن أخي حسين الجعفي عن عبد

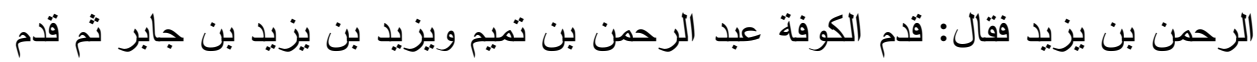

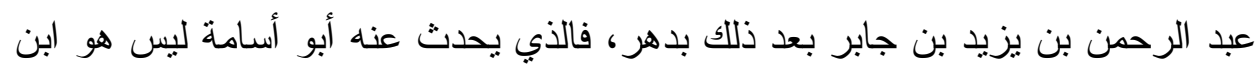

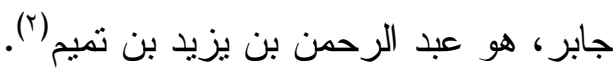

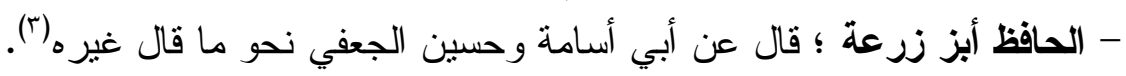

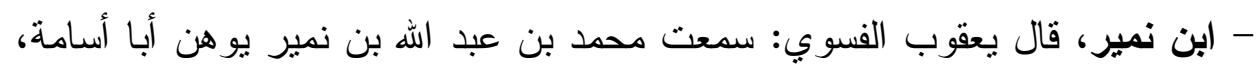

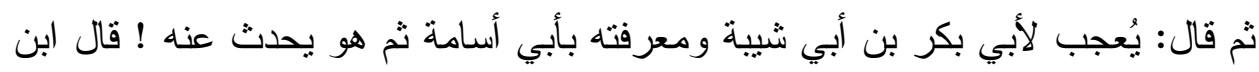

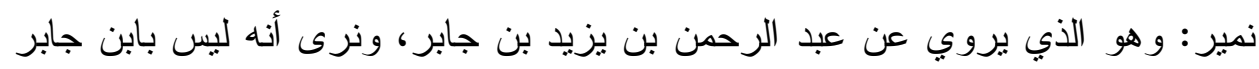

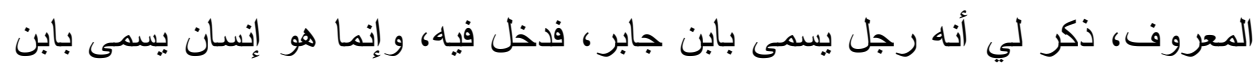

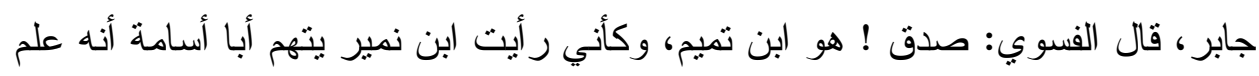

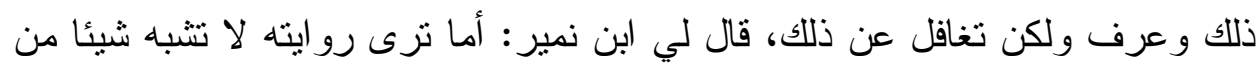

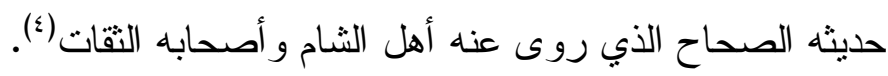

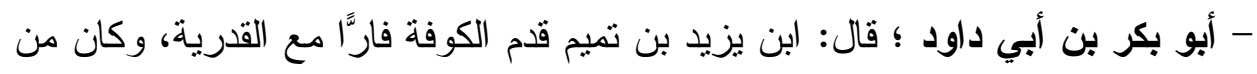

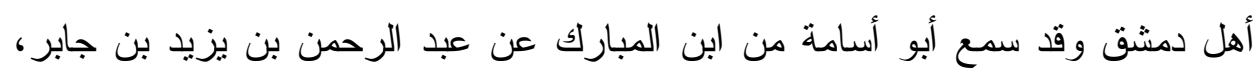

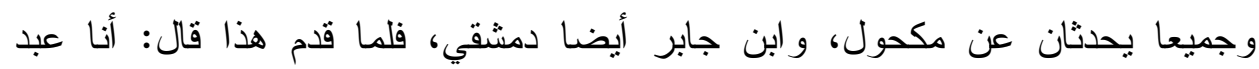

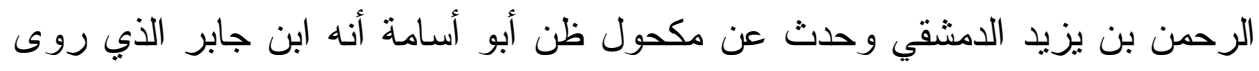

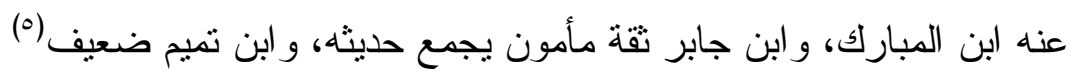

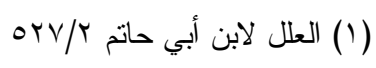

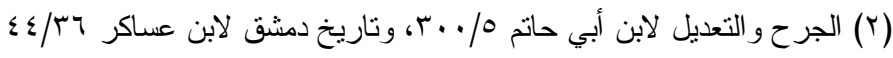

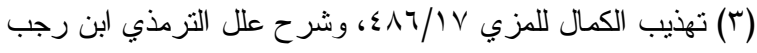

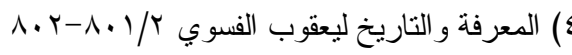

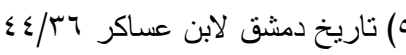


- الإمام أبو داود، وقال أبو داود : منروك الحديث، حدث عنه أبو أسامة وغلط في

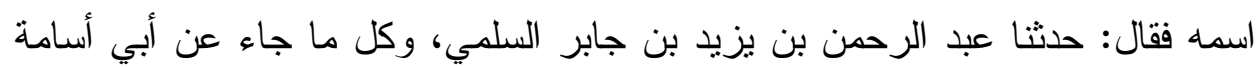
حدثنا عبد الرحمن بن يزيد فهو ابن تميم (1). - الحافظ (بن حبان ؛ قال: وقد روى لرين عنه الكوفيون أبو أسامة وحسين الجعفي

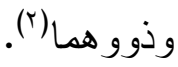
- الحافظ عمرو بن علي الفلاَّ ؛ قال: عبد الرحمن بن يزيد بن جابر ضعيف

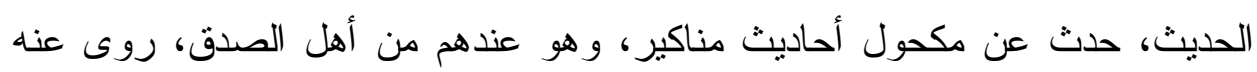
أهل الكوفة أحاديث مناكير (r).

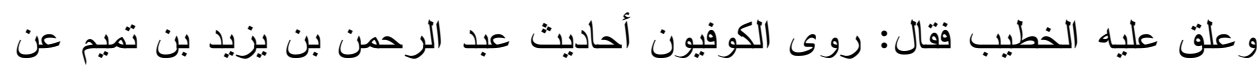

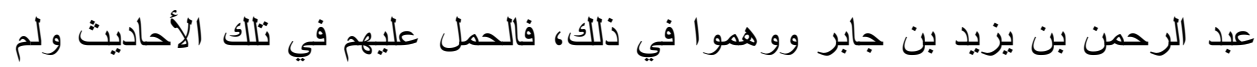

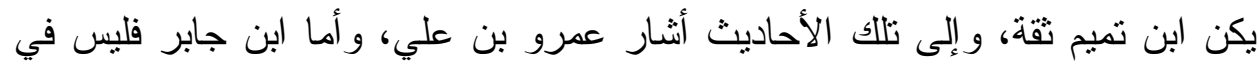

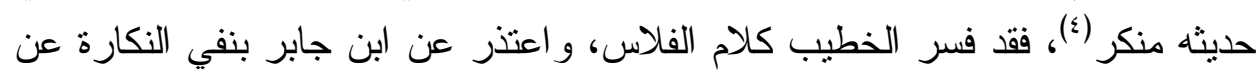
حديثه، فو هم من زعم أنه تعقبه، و اله أعلم. - الحافظ البزار ؛ قال: وهذا الحديث بهذا اللفظ لا نعلم أحدا يرويه إلا شداد (الصو اب:

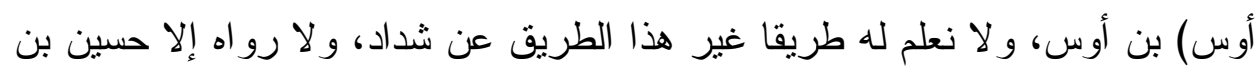

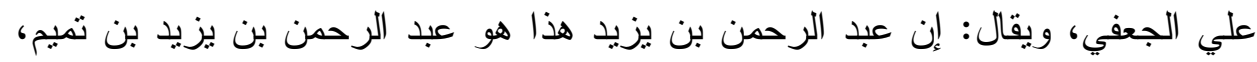

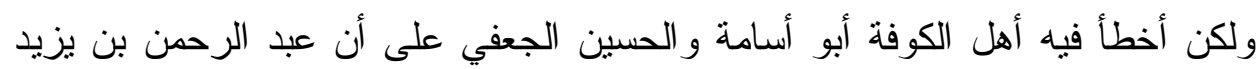

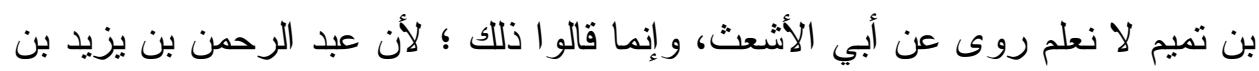
جابر ثقة، و عبد الرحمن بن يزيد بن تميم لين الحديث، فكان هذا الحديث فيه كلام منكر عن النبي صلى الله عليه وسلم فقالو ا: هو لعبد الرحمن بن تميم أنثبه (0).

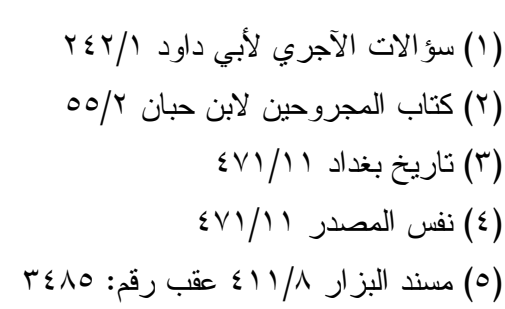


- الحافظ المنذري ؛ قال: وله علة دقيقة أثنار إلبها البخاري وغيره، ليس هذا موضعها، وقد جمعت طرقه في جزء (').

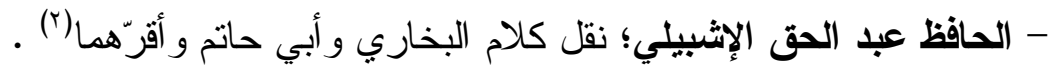

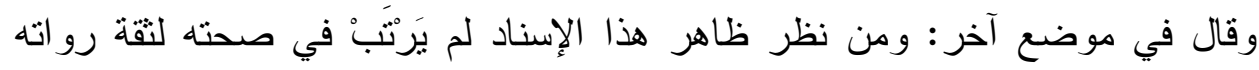

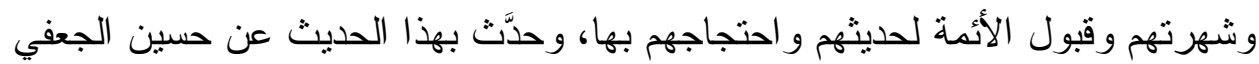

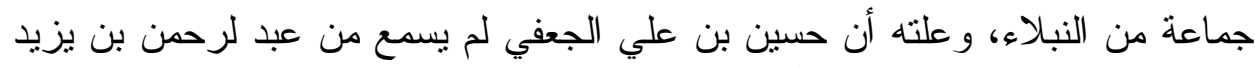

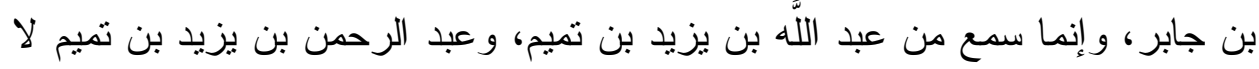

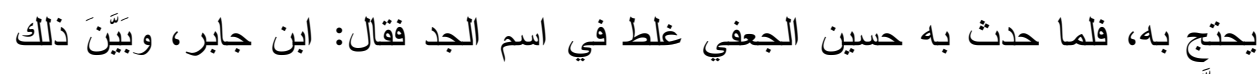

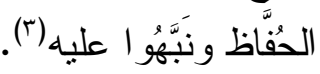

- الحافظ ابن القطان الفاسي، فقد اعتمد كلام الحفاظ في أبي أسامة وحسين الجعفي(؛). رد الارقطني على ابن حبان تبع ابن حبان من سبقه من الحفاظ فقال: أخطأ أبو أسامة و الحسين الجعفي فقالا: عبد هبد الرحمن بن يزيد بن جابر ، و إنما هو عبد الرحمن بن يزيد بن بن تمينم، وتعقبه الدارقطني

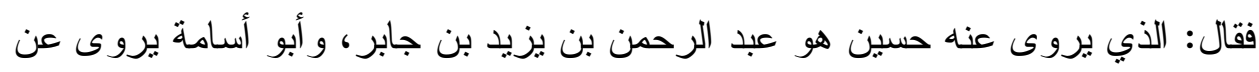

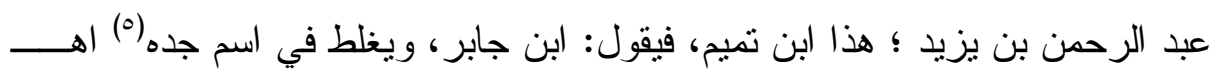

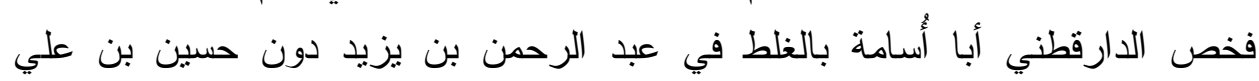
الجعفي، و على هذا فحديث حسين عن ابن جابر صحيح.

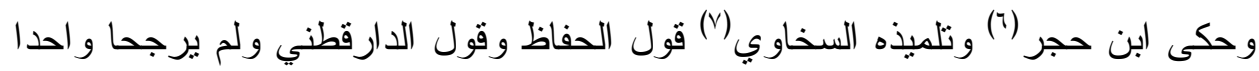
منهما.

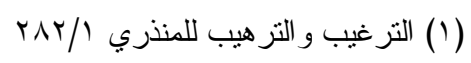

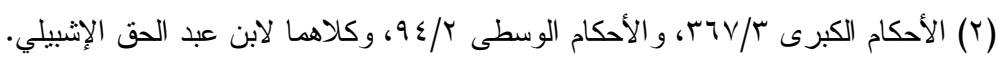

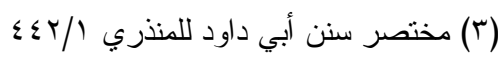

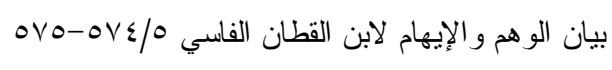

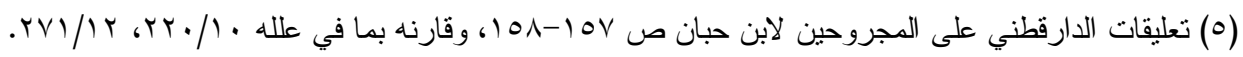

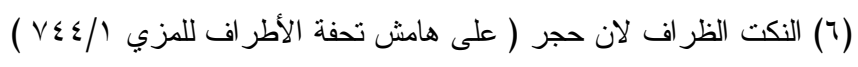

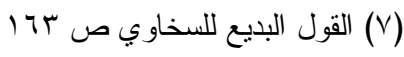


لكن انتصر له ابن عبد الهادي فقال: وهذا الذي قاله الحافظ أبو الحسن هو أقرب و أثنبه

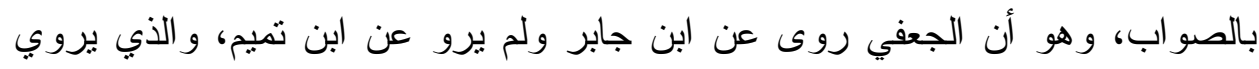

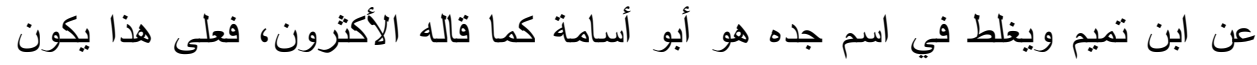
الحديث الذي رواه حسين الجعفي عن ابن جابر عن أبي الأشعث عن أوس حديثاً

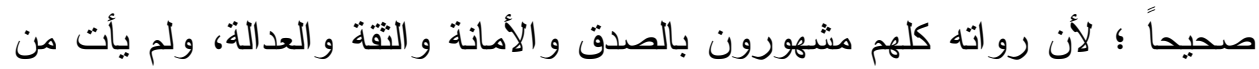
تكلم فيه و علله بحجة بينة (') .

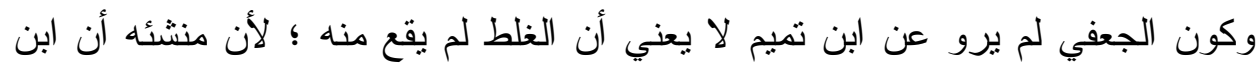

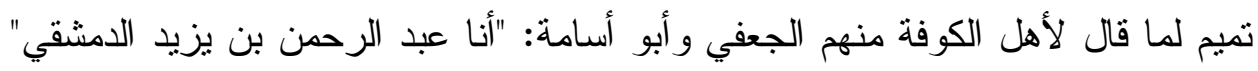

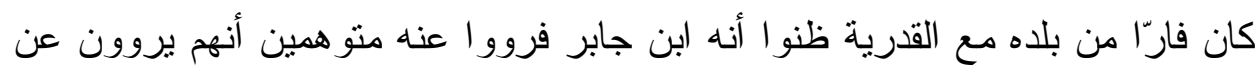

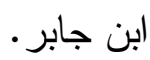

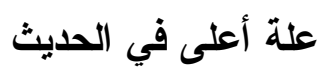
الحديث الثاني:

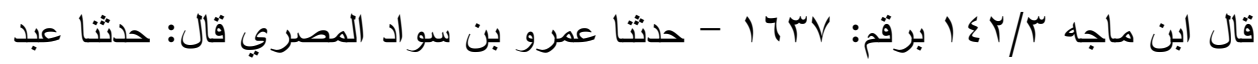

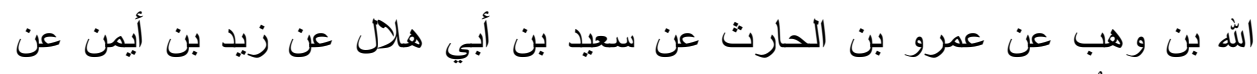

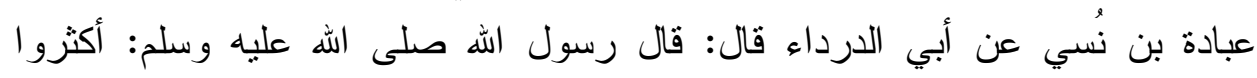

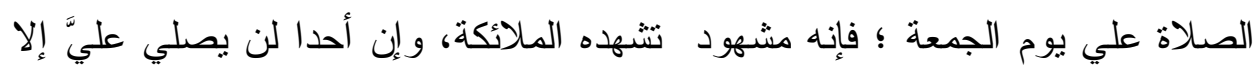

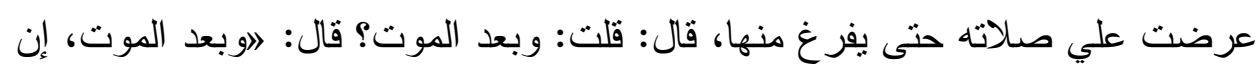

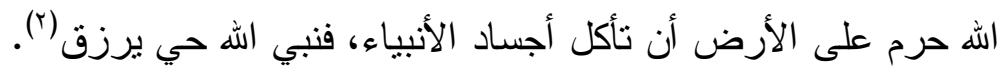
قال المنذري: رو اه ابن ماجه بإسناد جيد (). فيه ثناث علل: (1) أن عبادة ما أدرك أبا الدرداء ؛ قال ابن حبان: يروي عن جماعة من التابعين

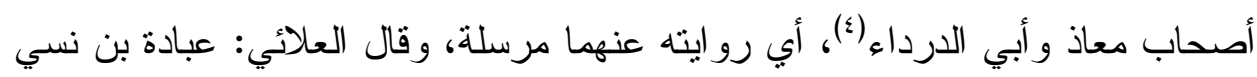

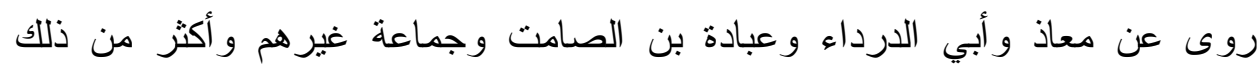

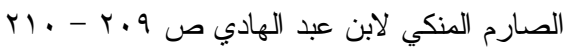

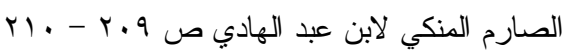

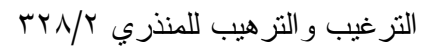

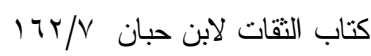


مراسيل(")، وقال البوصيري: عبادة بن نسي روايته عن أبي الدرداء مرسلة قاله

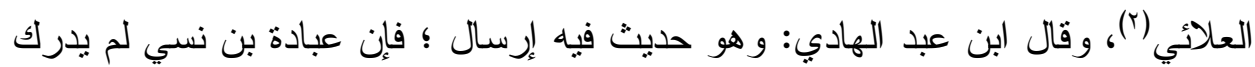

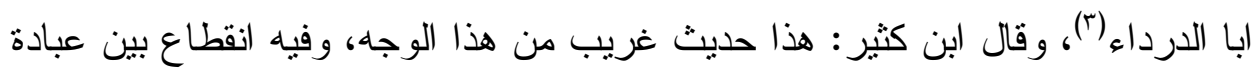

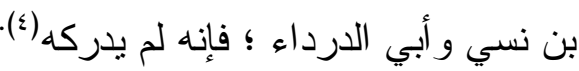

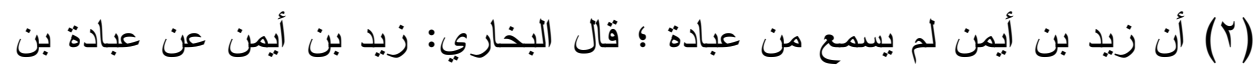

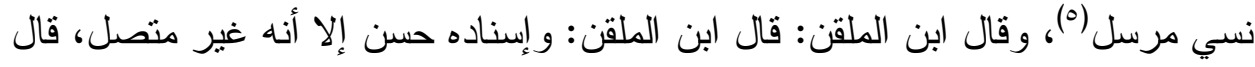

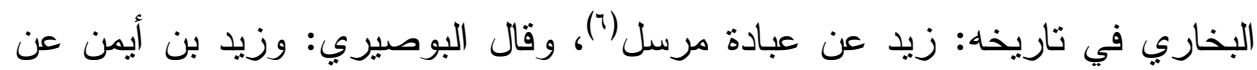

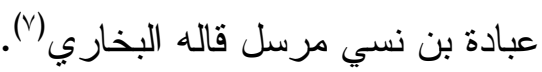

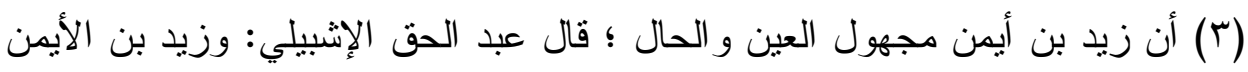

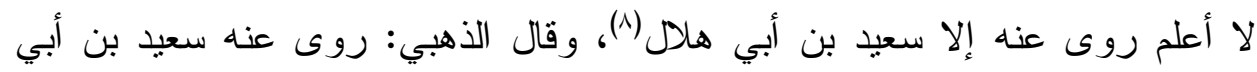

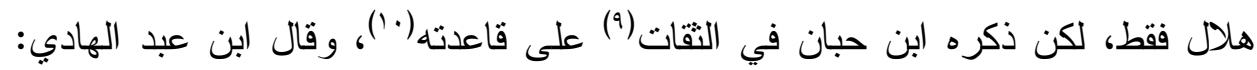

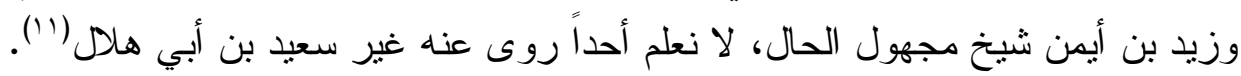

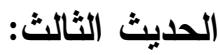

قال البيهقي: أخبرنا علي بن أحمد بن عبدان أنبأ أحمد بن عبيد ثنا الحسن بن سعيد ثنا

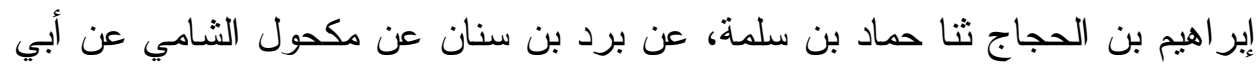

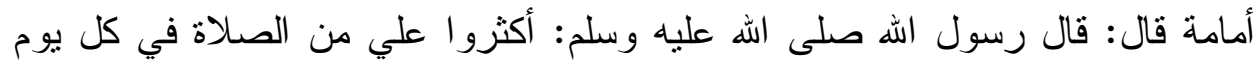

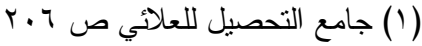

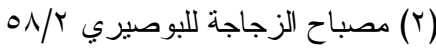

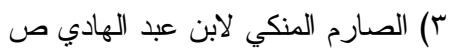

$$
\begin{aligned}
& \text { ( } \\
& \text { (0) التاريخ الكبير للبخاري كريزيز }
\end{aligned}
$$

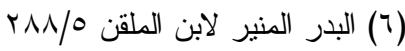

$$
\begin{aligned}
& \text { 0N/ مصباح الزجاجة للبوصبري (V) }
\end{aligned}
$$

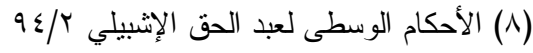

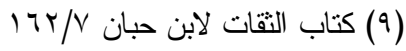

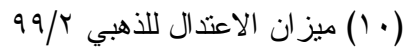

$$
\begin{aligned}
& \text { (1') الصارم المنكي لابن عبد الهادي ص (1) }
\end{aligned}
$$


جمعة ؛ فإن صلاة أمتي تعرض علي في كل يوم جمعة، فمن كان أكثر هم علي صلاة

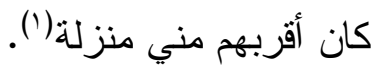

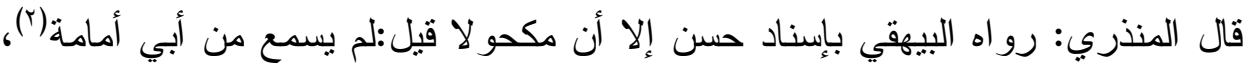

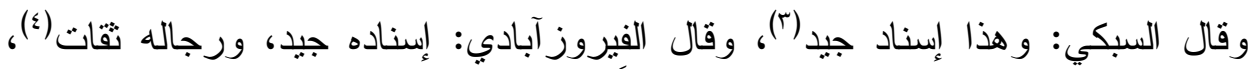

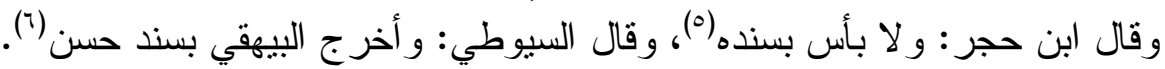

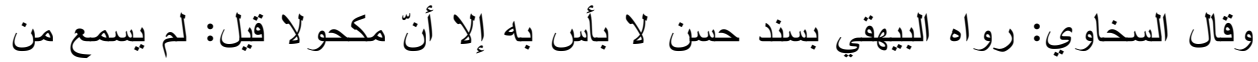

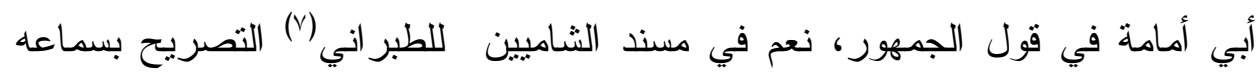
منه، وقد رو اه الديلمي في مسند الفردوس لله فأسقط منه ذكر مكحول وسنده ضعيف (^).

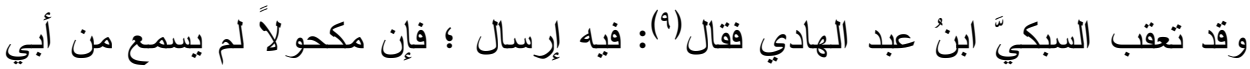

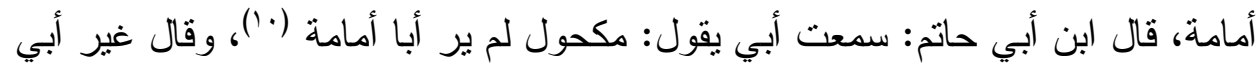

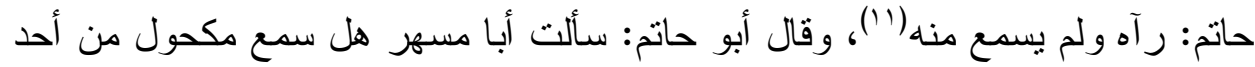

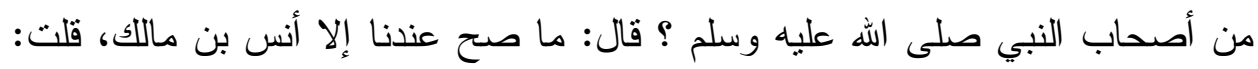

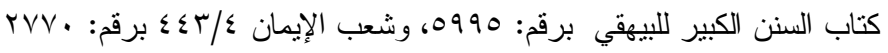

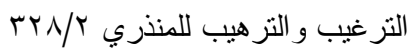

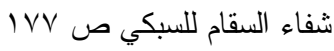

$$
\begin{aligned}
& \text { الصلات و البشر للفيروز آبادي ص بـاء }
\end{aligned}
$$

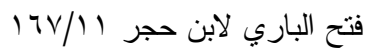

$$
\begin{aligned}
& \text { الخصائص الكبرى للسيوطي }
\end{aligned}
$$

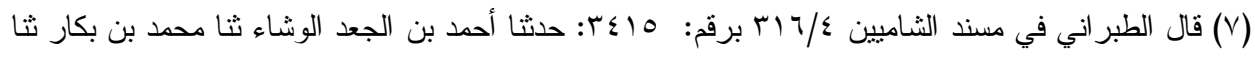

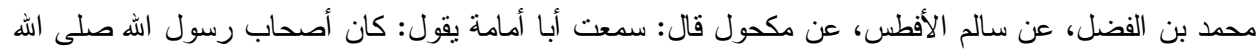

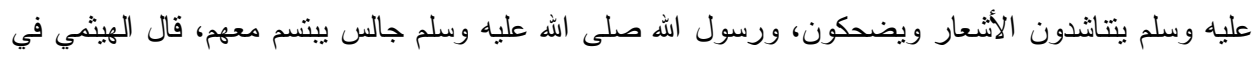

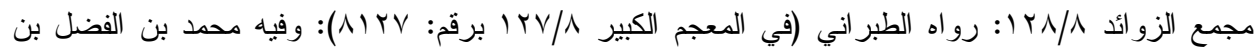
عطية، وهو متروك كذاب.

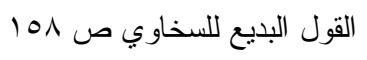

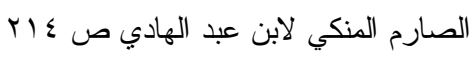

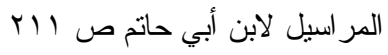

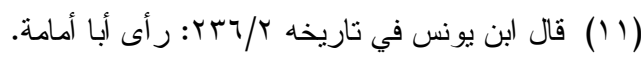


قلت: واثلة فأنكره(1)، وقال ابن معين: ليس يثيّتّنه -أي مكحو لا- في رواية أبي (أمامة)( وقال ابن عدي: يروي مكحول عن صحابة لم يدركهم مثل أبي الدرداء و عائشة وو اثلة

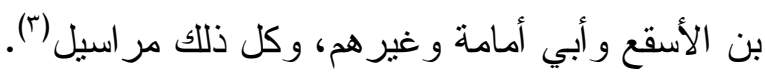

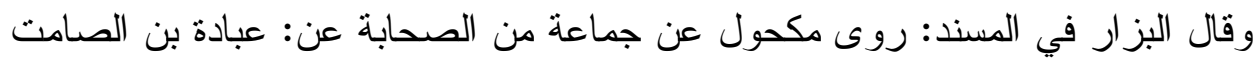
و أبي الدرداء وحذيفة وأبي هريرة وجابر، ولم يسمع منهم ولم بدركهم، و إنما أرسل

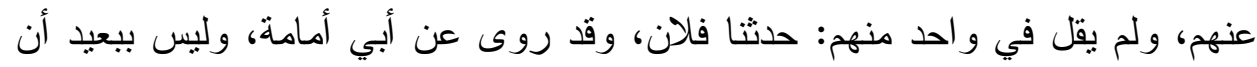

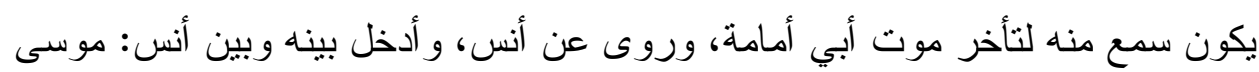

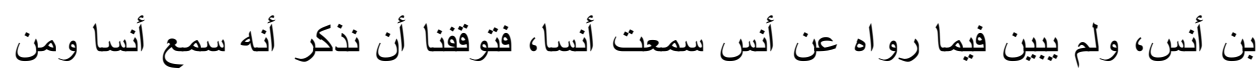

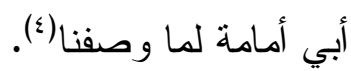

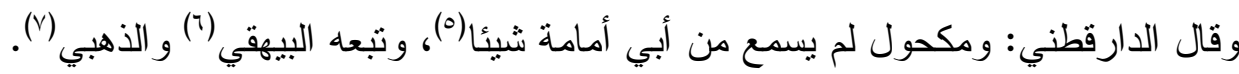

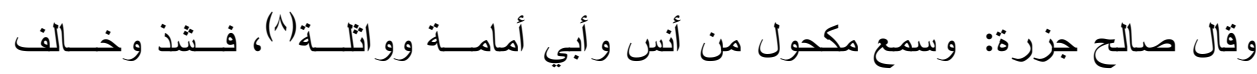
الجمهور

ورُوي ما يدل على رؤية مكحول لأبي أمامة ؛ روى الخطيب(9) من طريق بزيد بن زياد القرشي عن سليمان بن حبيب المحاربي قال: دخلت مسجد حمص، فيه فإذا مكحول

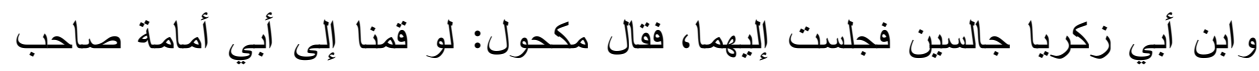

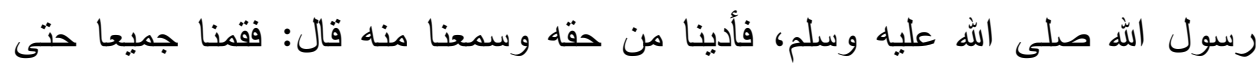

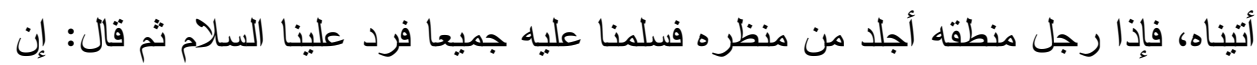

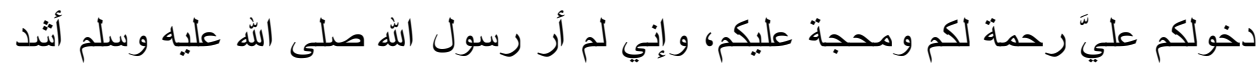

$$
\begin{aligned}
& \text { (1) المر اسيل لابن أبي حاتم ص (1) (1) }
\end{aligned}
$$

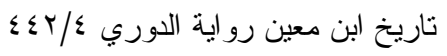

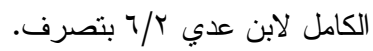

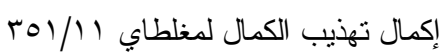

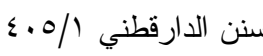

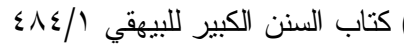

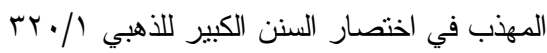

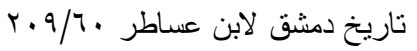

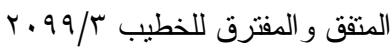


خوفا على هذه الأمة من الكذب و العصبية، ألا و إنه أمرنا أن نحذركم ونبلغكم ذلك عنه

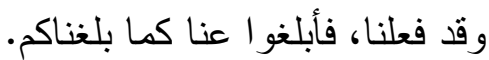

وفي سنده يزيد بن زياد القرشي، وهو و واه جدا (')، ولعل الذهبي قال لأجل ذلك: وأخطأ من روى أنه دخل على أبي أمامة(ب). الحديث الر ابع:

قال البيهقي: ؟99ه - أخبرنا أبو سهل أحمد بن محمد بن إبر اهيم المهر اني أنبأ محمد

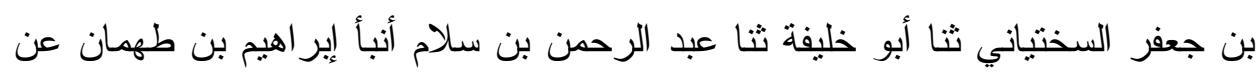

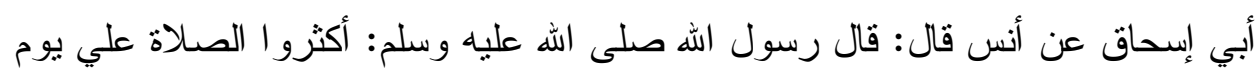
الجمعة وليلة الجمعة ؛ فمن صلى علي صلي صلاة صلى الله عليه عشرا ـاله 


\section{الخاتمة \\ نتائج البحث}

(1) أن الصلاة على النبي صلى الله عليه وسلم من أفضل القربات. (Y) أنه تستحب الصلاة عليه في كل زمان ومكان.

(r) أنه لم يصح شيء في فضل الصلاة على النبي صلى الله عليه وسلم يوم الجمعة فئل بخصوصها.

(ع) أن أوس بن أوس رضي الله عنه قال: قال رسول الله صلى الله عليه وسلم: إن من

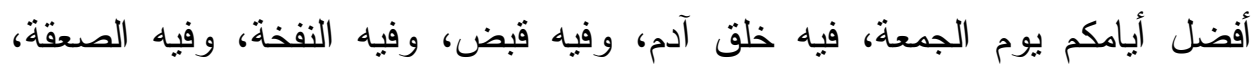

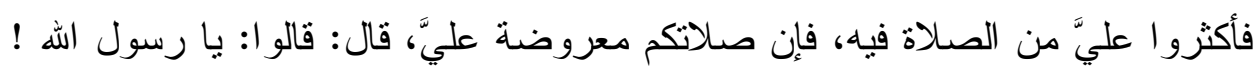

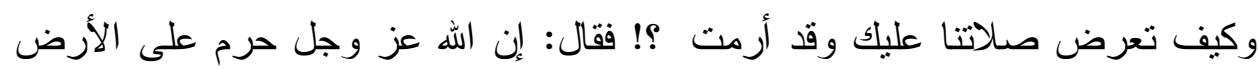
أجساد الأنبياء ظاهره إسناده الصحة، لكنه معلول نبه على ذلك كبار أئمة الحديث. (0) أن حديث أبي الدرداء قال: قال رسول اله صلى الله عليه وسلم: أكثروا الصلاة

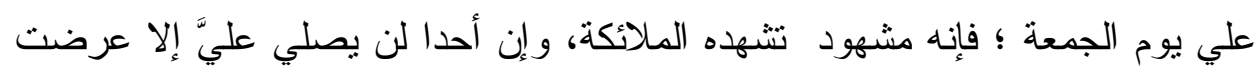

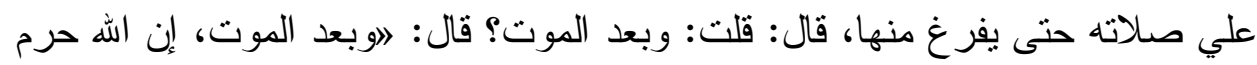

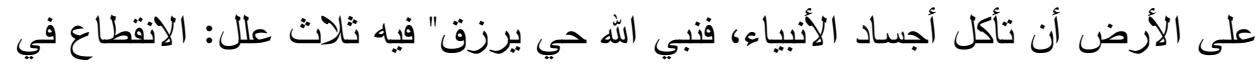
موضعين، و الجهالة.

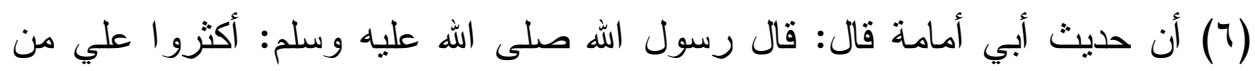

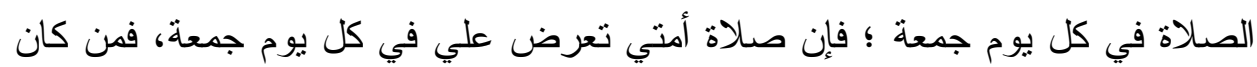

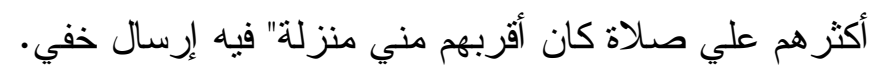

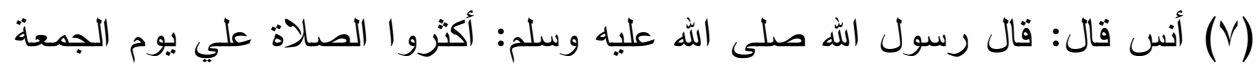

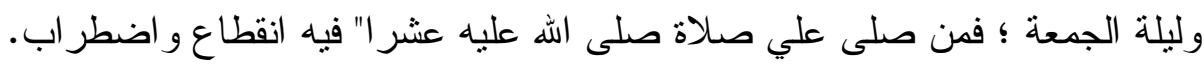




\section{مصادر البحث}

القر آن الكريم - مصحف المدينة النبوية للنشر الحاسوبي - مجمع الملك فهـــ لطباعـــة المصحف الثريف - المدينة المنورة.

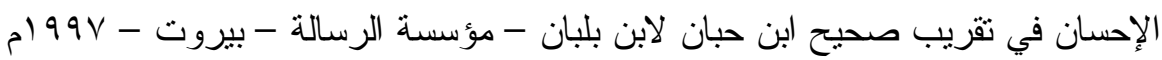

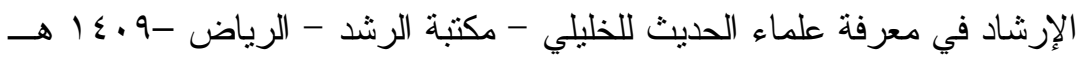

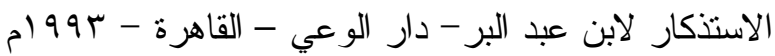

$$
\begin{aligned}
& \text { إعلام الموقِّين لابن القيم - دار الجيل - بيروت الإن }
\end{aligned}
$$

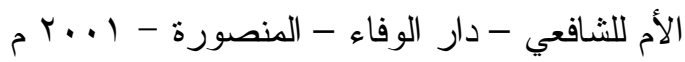

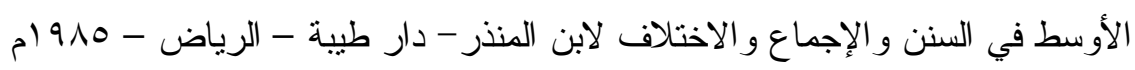

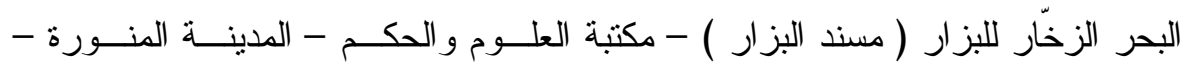
م) 911

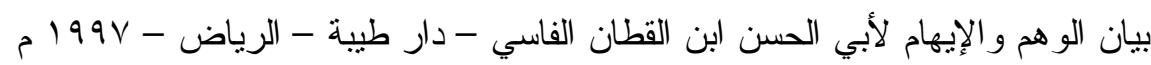

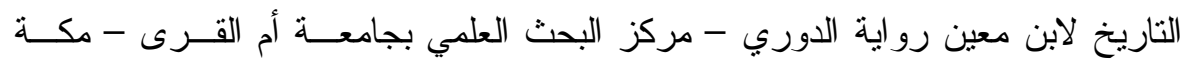

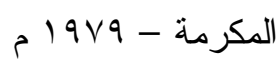

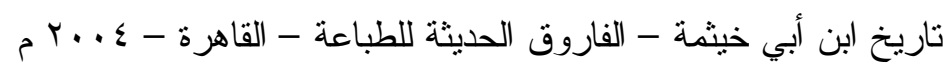

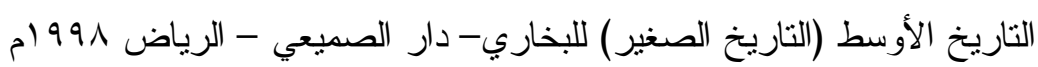

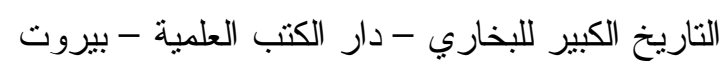

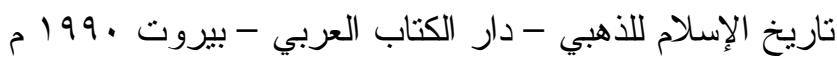

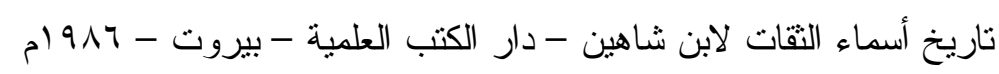

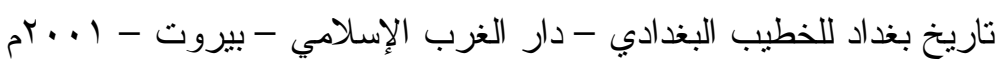
تاريخ مدينة دمشق لابن عساكر - دار الفكر - بيروت 1990 تحفة الأحوذي بشرح جامع الترمذي للمباركفوري - دار إحياء التزر اث العربي - بيروت تحفة المحتاج بشرح المنهاج لابن حجر الهيتمي - مطبعة مصطفى محمد - القاهرة

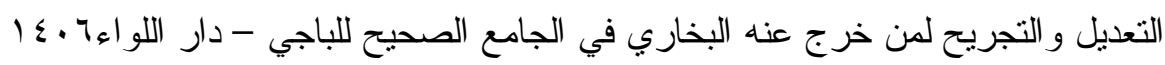

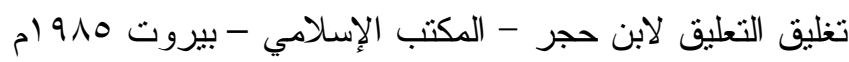

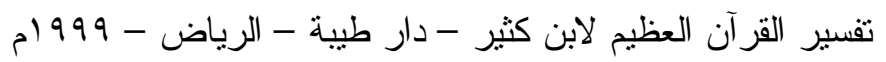

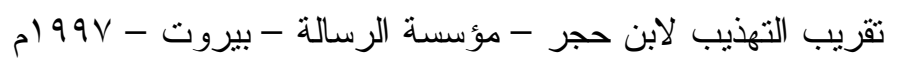




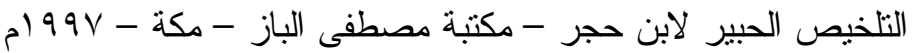

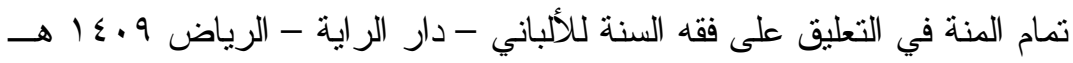

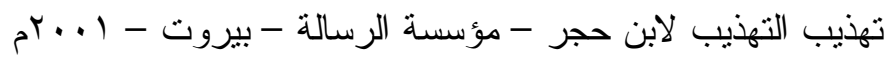

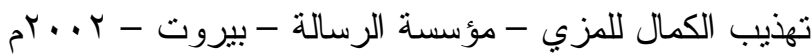

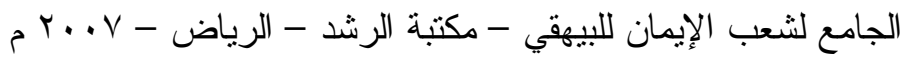

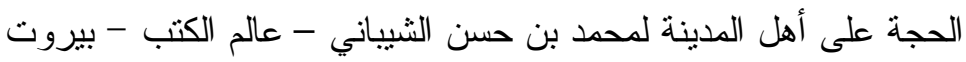

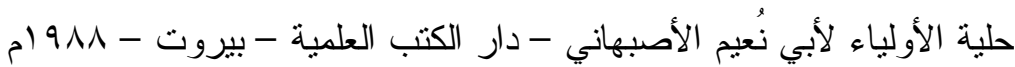

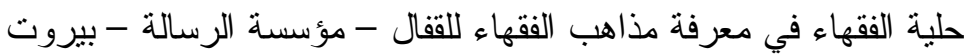

الدراية في تخريج أحاديث الهداية لابن حجر - دار المعرفة - بيروت.

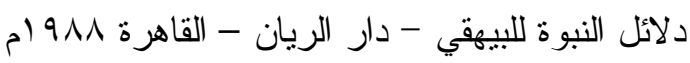

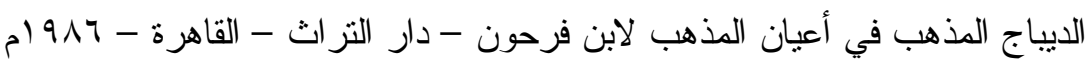

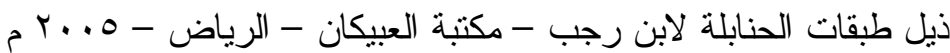

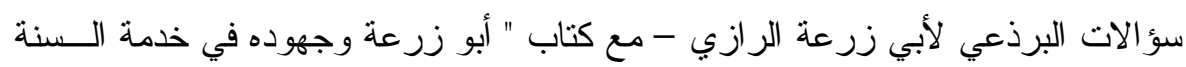

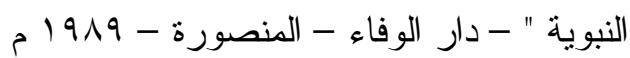

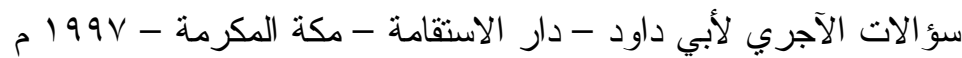

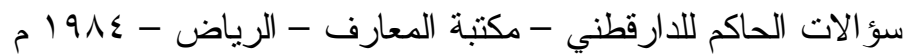

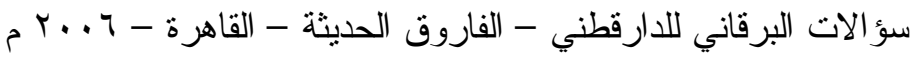

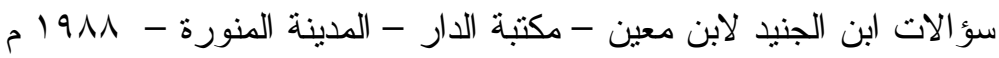

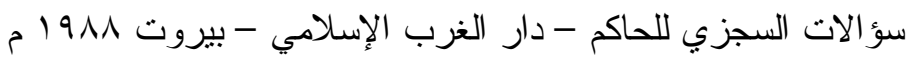

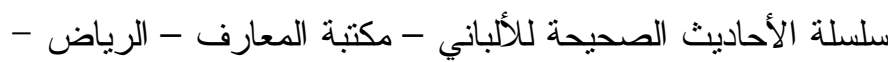

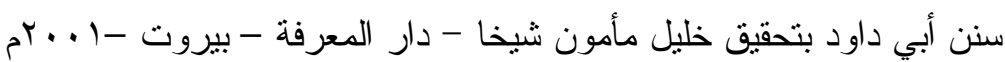

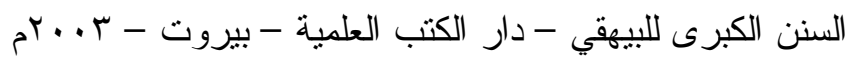

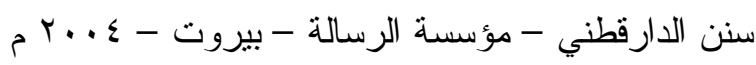

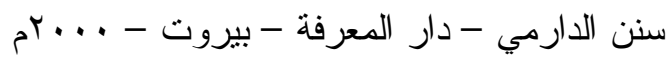

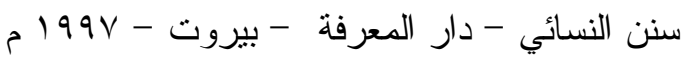

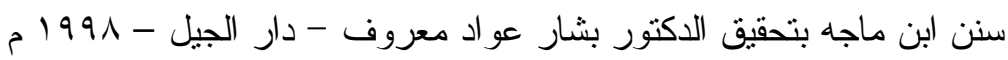

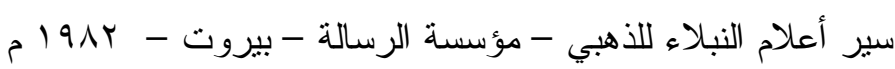




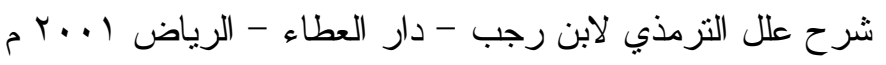

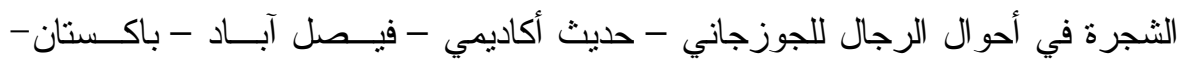
م 199.

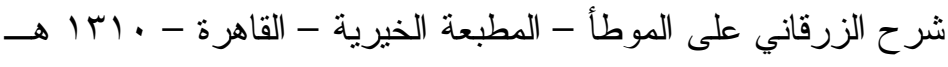

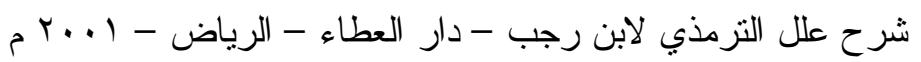

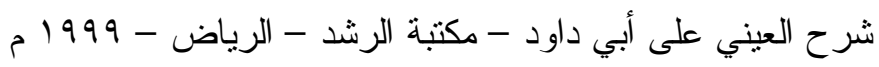

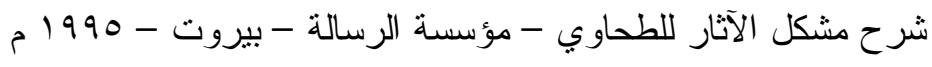

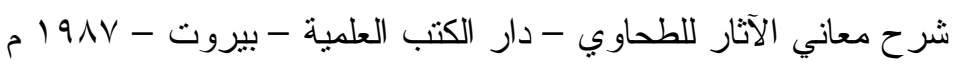

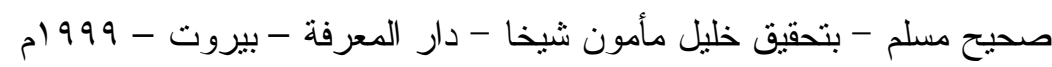

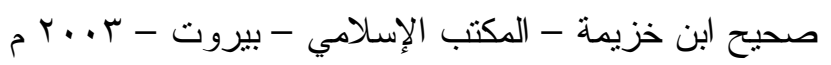

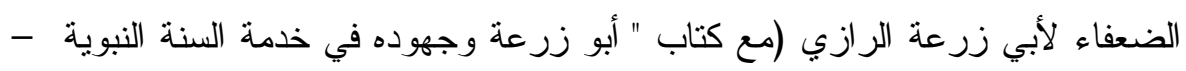

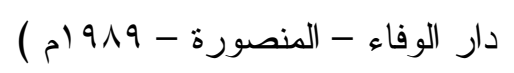

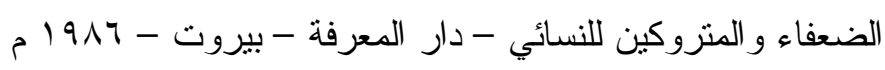

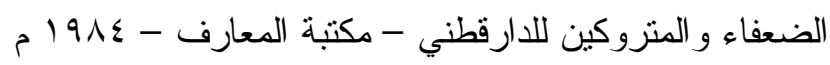
طبقات ابن سعد ( انظر : كتاب الطبقات الكبير )

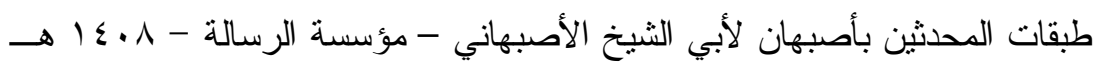
عارضة الأحوذي بشرح صحيح الترمذي لابن العربي - دار الكتب العلمية - بيروت. العلل لابن أبي حاتم - دار المعرفة - بيروت - 191

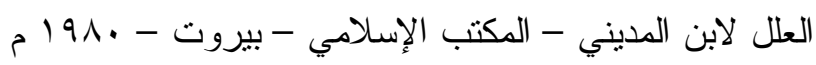

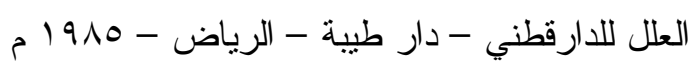
العلل الصغير للترمذي - انظر سنن الترمذي لإني

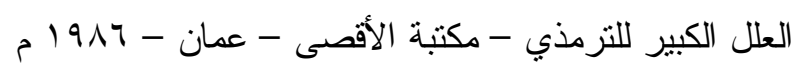

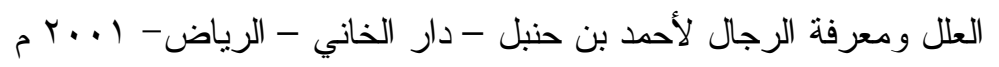

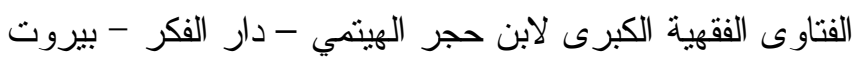

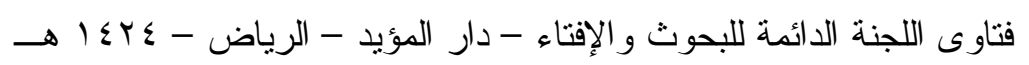

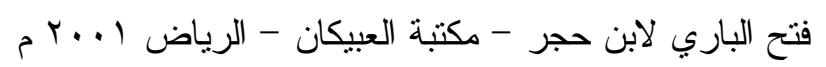
فتح الباري لابن رجب - مكتب تحقيق دار الحرمين - القاهرة - 1997 
القبس في شرح الموطأ لابن العربي - دار الغرب الإسلامي - بيروت - 1999 م الكاثف عن حقائق السنن للطيبي - مكتبة نز ار - مكة المكرمة - 199 ل

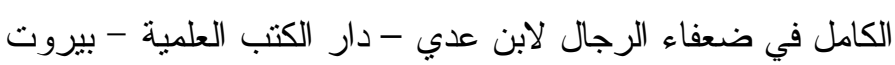

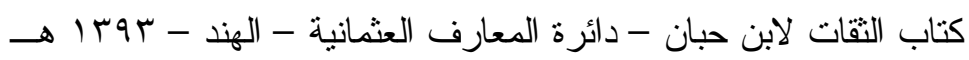

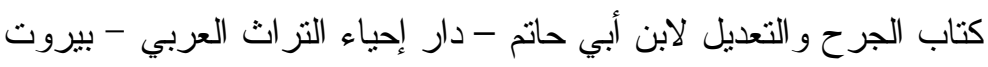

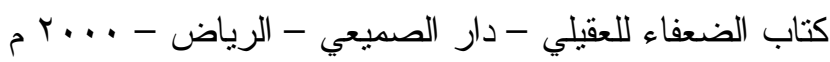

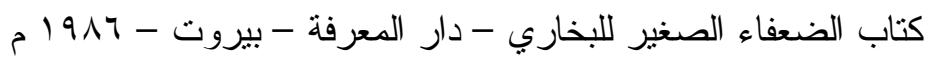
كتاب الطبقات الكبير لابن سعد - مكتبة الخانجي - القاهرة

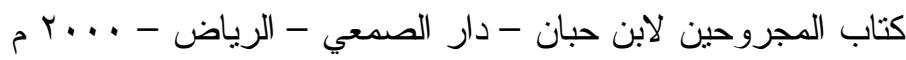

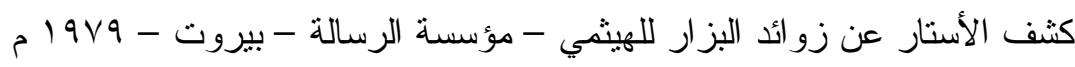

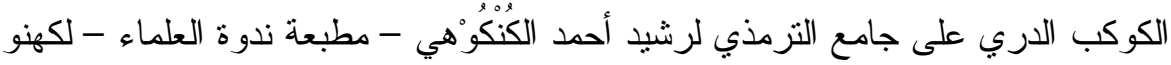
م 19v0-

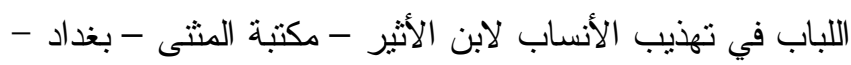

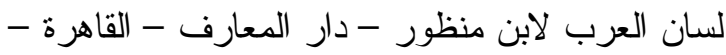
لسان الميزان لابن حجر - مكتب المطبوعات الإسلامية - حلب.

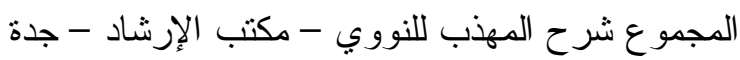

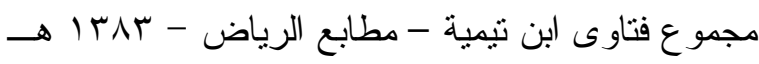

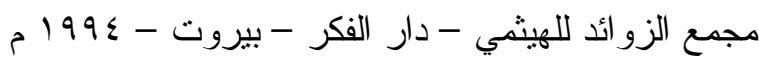

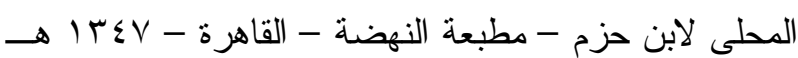

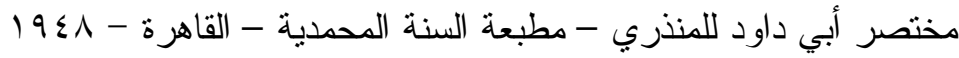

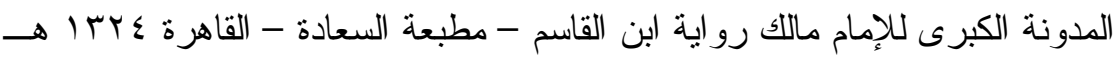

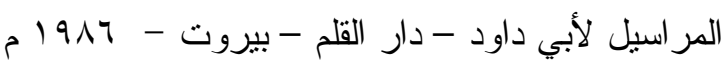

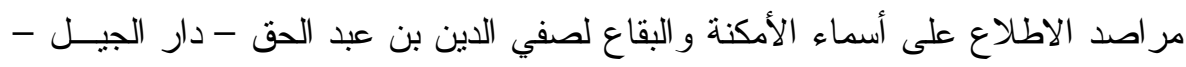

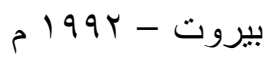

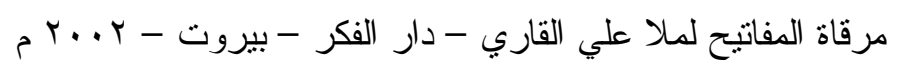

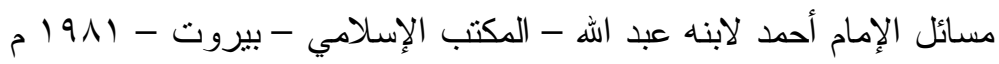


المسالك في شرح موطأ مالك لابن العربي المالكي - دار الغرب الإسلامي - بيروت r...v

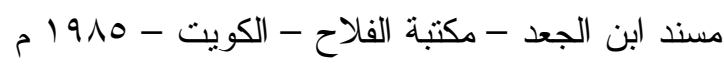

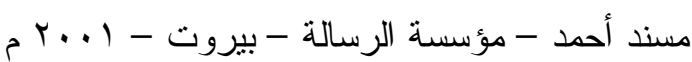

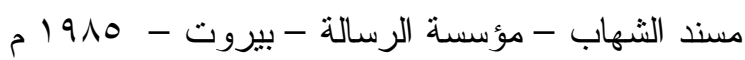

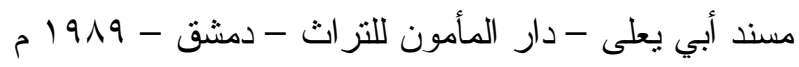

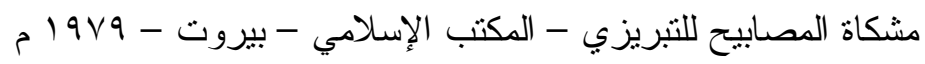

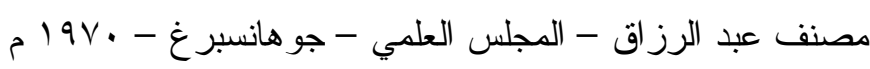

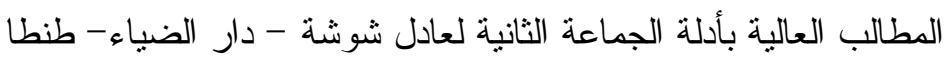

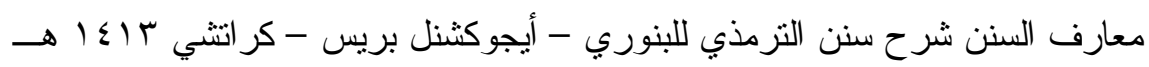

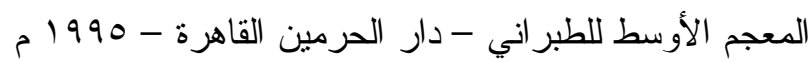

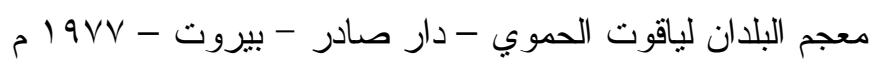

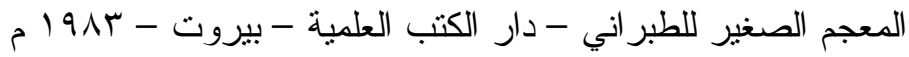
المعجم الكبير للطبر اني - مكتبة ابن تيمية - القاهرة

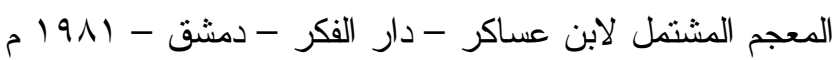

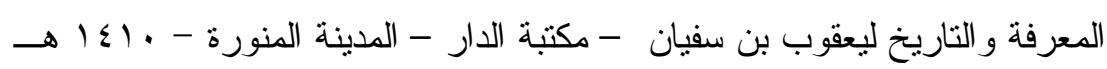

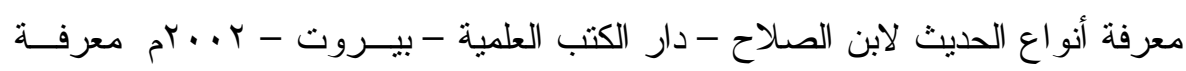

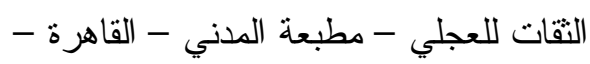

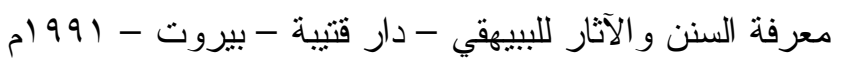

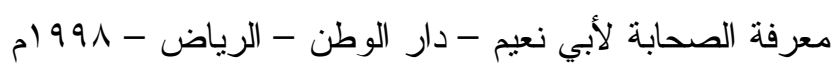

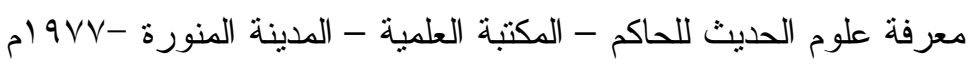

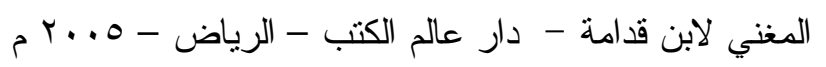

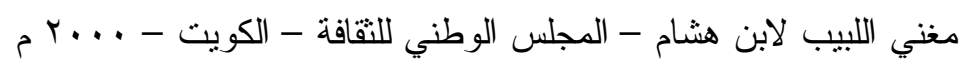

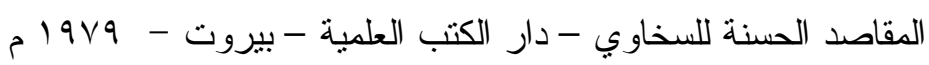

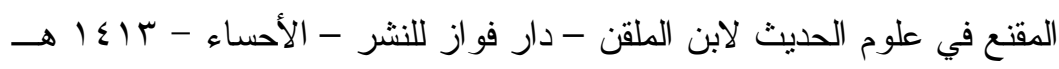

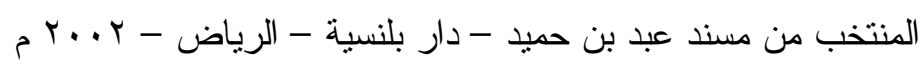

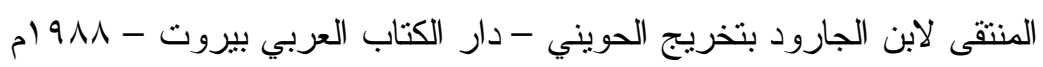


المنهاج في شرح صحيح مسلم بن الحجاج للنووي - دار المعرفة - بيروت - .... بام

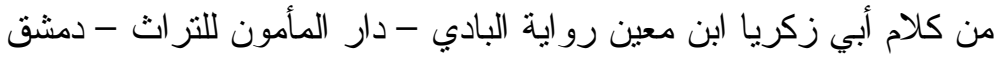

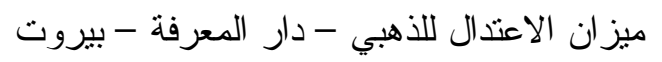

نزهة النظر في توضيح نخبة الفكر لابن حجر -بتحقيق عبد اله الرحيلي -1...

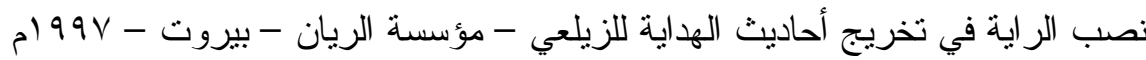

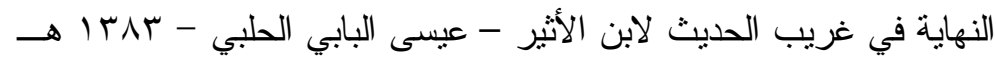

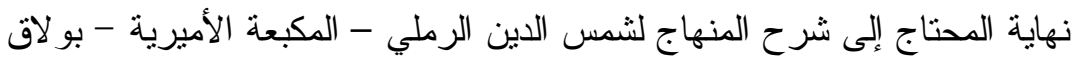

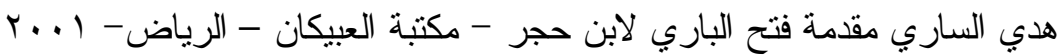


